\title{
The TRPS1 transcription factor: androgenic regulation in prostate cancer and high expression in breast cancer
}

\author{
Glenn T G Chang, Mila Jhamai, Wytske M van Weerden ${ }^{1}$, Guido Jenster ${ }^{1}$ \\ and Albert $O$ Brinkmann
}

\author{
Department of Reproduction and Development, Erasmus MC, Rotterdam, The Netherlands \\ ${ }^{1}$ Department of Urology, Josephine Nefkens Institute, Erasmus MC, Rotterdam, The Netherlands \\ (Requests for offprints should be addressed to G T G Chang; Email: gtg.chang @erasmusmc.nl)
}

\begin{abstract}
TRPS1 mRNA is more highly expressed in androgen-dependent lymph node carcinoma of prostatefast growing colony (LNCaP-FGC) compared with androgen-independent lymph node carcinoma of prostate-lymph node original (LNCaP-LNO) prostate cancer cell lines. Furthermore, TRPS1 mRNA expression is down-regulated by androgens in LNCaP-FGC cells, a process mediated by the androgen receptor (AR). Here, we present TRPS1 protein expression in human prostate cancer material derived from a panel of six androgen-dependent and eight androgen-independent human prostate cancer xenografts. TRPS1 protein is expressed in all androgen-dependent xenografts, which also express AR and prostate-specific antigen (PSA). Androgen withdrawal by castration resulted in an increase in TRPS1 protein in two androgen-dependent xenografts, indicating relieved repression by action of AR. TRPS1 protein is expressed in four androgen-independent xenografts and is low or absent in the other four androgen-independent xenografts. Androgen withdrawal by castration demonstrates that TRPS1 protein levels remain the same in 1 androgen-independent xenograft, most likely due to the lack of AR expression. These data show that TRPS1 protein expression is regulated by androgens via the AR in human prostate cancer xenografts.

Analysis of TRPS1 mRNA expression in normal and tumour tissue of the prostate and 18 other human tissues, showed that TRPS1 had the highest mRNA expression levels in normal and tumour tissues of breast. In addition, high TRPS1 mRNA and protein expression levels were observed in four out of five human breast cancer cell lines.

In conclusion, TRPS1 protein expression is down-regulated by androgens in human prostate cancer, and analysis of TRPS1 mRNA expression levels in several human tissues showed that the highest levels were observed in normal and tumour breast tissue.
\end{abstract}

Endocrine-Related Cancer (2004) 11 815-822

\section{Introduction}

Prostate cancer is the second leading cause of cancerrelated deaths and the most frequently diagnosed cancer in men in Western countries (Weir et al. 2003, Jemal et al. 2004). Initially, prostate cancer is androgen-dependent and growth is mediated by the androgen receptor (Culig et al. 2002, Gelmann 2002). Treatment can be achieved by eliminating androgen action via androgen withdrawal using chemical or surgical castration (Huggins \& Hodges 1941). However, prostate cancer will progress to androgen-independency, a process that is not fully understood
(Feldman \& Feldman 2001, Arnold \& Isaacs 2002). Therefore, effective treatment of androgen-independent prostate cancer is not yet available (Martel et al. 2003). Characterization of the genes, and their encoded proteins, that are expressed during prostate cancer progression is important to understanding the disease, and ultimately the development of novel treatment therapies.

We have reported GC79 mRNA as differentially expressed between androgen-dependent and androgenindependent lymph node carcinoma of prostate ( $\mathrm{LNCaP})$ prostate cancer cell lines (Chang et al. 1997). GC79 is identical to tricho-rhino-phalangeal syndrome (TRPS)1, 
and may potentially be involved in prostate cancer development. The domain structure of the TRPS1 protein depicts a multitype zinc finger protein of 1281 amino acid residues, consisting of seven classical $\mathrm{C} 2 \mathrm{H} 2$ type zinc fingers, one GATA C4 type zinc finger, and two Ikaros C2H2 type zinc fingers (Chang et al. 2000, Momeni et al. 2000). The TRPS1 protein has an apparent molecular mass of $160 \mathrm{kDa}$ and binds to DNA sequences harbouring a GATA or inverse GATA motif (Malik et al. 2001, Chang et al. 2002, van den Bemd et al. 2003). TRPS1 functions as a transcription factor and represses the activity of GATA4 transcription factor (Malik et al. 2001). Recently, it was reported that repression of TRPS1 activity can be relieved by binding of TRPS1 to either the dynein light chain protein LC8a or the RING Finger protein SNURF/RNF4 (Kaiser et al. 2003a,b). SNURF/RNF4 has been reported to function as a cofactor for several steroid receptors, including the androgen receptor (Moilanen et al. 1998). More recently, we have reported that TRPS1 represses the expression of prostate-specific antigen, suggesting a possible role in prostate cancer (van den Bemd et al. 2003). The TRPS1 gene is localised on human chromosome 8q23-24.1, a region highly amplified in several cancers, especially prostate cancer (Visakorpi et al. 1995, Cher et al. 1996, Nupponen et al. 1998) and breast cancer (Kallioniemi et al. 1994, Tirkkonen et al. 1998). This indicates that TRPS1 may be overexpressed during development or progression of these endocrine-related cancers.

It has also been reported that mutations in the TRPS1 gene cause TRPSs (Momeni et al. 2000, Lüdecke et al. 2001). TRPS is a rare disorder characterised by craniofacial malformation and skeletal abnormalities.

To gain more insight into the involvement of TRPS1 in prostate cancer progression, we have analysed TRPS1 protein expression in human prostate cancer. We show, for the first time, that TRPS1 protein is down-regulated in vivo by androgens using a panel of human prostate cancer xenograft models (van Weerden et al. 1996, van Weerden \& Romijn 2000). In addition, TRPS1 mRNA expression was studied in normal and tumour tissue material obtained from cancer patients.

\section{Materials and methods}

\section{Human cancer cell lines and prostate cancer xenografts}

Human androgen-dependent prostate cancer cell line lymph node carcinoma of prostate-fast growing colony (LNCaP-FGC) and androgen-independent prostate cancer cell line androgen-independent lymph node carcinoma of prostate-lymph node original (LNCaP-LNO) were gifts from JS Horoszewicz (Buffalo, NY, USA). Cells were cultured in RPMI media containing normal fetal calf serum (FCS) and characterised as described by Horoszewicz et al. (1983) and Chang et al. (1997). Human androgen-independent prostate cancer cell lines (DU145 and PC3) and human breast cancer cell lines (ZR-75-1, MCF-7, T-47D, SK-BR-3 and MDA-MB-231) were obtained from the American Type Culture Collection (ATCC, Manassas, VA, USA) and maintained in their appropriate culture media containing FCS as recommended. For hormone experiments of LNCaP-FGC cell lines, culture medium was discarded when cells reached $70-80 \%$ confluency, and cells were hormone depleted by replacing with culture media containing dextran charcoal treated (DCC) FCS for $24 \mathrm{~h}$. The synthetic androgen R1881 (methyltrienolone) (NEN, Boston, MA, USA) was added to final concentrations of $0.1 \mathrm{nM}$ and $10 \mathrm{nM}$. After $24 \mathrm{~h}$, culture media was discarded and cells were washed twice with phosphate buffered saline (PBS). Total RNA and whole protein lysates were isolated from cells as described in Northern blot analysis and Western blot analysis sections, respectively.

Human prostate cancer xenografts (PC82, PC133, PC135, PC295, PC310, PC324, PC329, РC339, РC346, PC346I, PC346B, PC346BI, PC374 and PC374F) were routinely propagated in male nude Naval Medical Research Institute (NMRI) mice (Harlan, Horst, The Netherlands) as described previously (van Weerden et al. 1996, van Weerden \& Romijn 2000). For castration experiments, tumour-bearing mice (PC295 and PC310) were supplemented with silastic testosterone implants. Androgen withdrawal was performed by castration under hypnorm anaesthesia (Janssen Pharmaceuticals, Oxford, UK), followed by removal of the silastic testosterone implant (Sigma). Mice were sacrified 0, 4, 7, and 21 days after castration. Tumours were removed, cut into small pieces and either fixed in $4 \%(\mathrm{v} / \mathrm{v})$ buffered formalin and paraffin embedded for histochemical analysis or snap frozen in liquid nitrogen and stored at $-80^{\circ} \mathrm{C}$ for Western blot analysis. The paraffin-embedded material was routinely stained using haematoxylin and eosin. All animal studies were approved by the Animal Experiments Committee under the National Experiments on Animals Act and adhered to the rules laid down in this national law that serves the implementation of Guidelines on the protection of experimental animals by the Council of Europe (1986), Directive 86/609/EC. Animals were maintained at the Erasmus University Center for Animal Research (EDC) of the Erasmus MC, Rotterdam, The Netherlands.

\section{Western blot analysis}

Whole protein extracts from cell lines and xenografts were isolated. Cells were briefly scraped in lysis buffer $(40 \mathrm{mM}$ Tris $\mathrm{HCl}, \mathrm{pH} 7.4,5 \mathrm{mM}$ EDTA, $10 \%$ (v/v) glycerol, 
$0.5 \mathrm{mM}$ sodium orthovanadate, $10 \mathrm{mM}$ dithiothreitol (DTT), $10 \mathrm{mM} \mathrm{Na} \mathrm{NoO}_{4}, 50 \mathrm{mM} \mathrm{NaF}, 0.5 \%$ (w/v) deoxycholate, $0.08 \%(\mathrm{w} / \mathrm{v})$ sodium dodecyl sulphate (SDS), 1\% (v/v) Triton X-100, $0.6 \mathrm{mM}$ phenylmethylsulfonyl fluoride (PMSF), $0.5 \mathrm{mM}$ bacitracin and Complete (1:50), a protease inhibitor cocktail (Roche, Mannheim, Germany)). After lysing the cells on ice for $10 \mathrm{~min}$, extracts were centrifuged for $10 \mathrm{~min}$ at 100000 r.p.m. at $4^{\circ} \mathrm{C}$ to remove cell debris. Protein content was determined in the supernatant using the Bradford dye-binding assay (Bio-Rad, Hercules, CA, USA). Tissues from xenografts were homogenised in the same lysis buffer by firm vortexing, incubated on ice and centrifuged as described for the cell lines.

Cellular or tissue protein extracts $(20 \mu \mathrm{g})$ were loaded on a 7\% SDS-polyacrylamide slabgel. After electrophoresis, proteins were blotted on nitrocellulose membranes (Schleicher \& Schuell, Keene, NH, USA), and blocked using 5\% (w/v) skim milk powder (Elk, Campina Melk Unie, Eindhoven, The Netherlands) in PBS containing $0.1 \%$ (v/v) Tween 20 (PBS/T). Detection of TRPS1 protein was performed overnight at $4{ }^{\circ} \mathrm{C}$ using rabbit polyclonal anti-TRPS1 antibodies SN653 (1:2000) directed against the N-terminus of TRPS1 (Chang et al. 2002). After washing three times for $5 \mathrm{~min}$ with $\mathrm{PBS} / \mathrm{T}$, the filters were incubated for $60 \mathrm{~min}$ with horseradish peroxidaseconjugated goat anti-rabbit antibody (1:2000) (Sigma, St Louis, MO, USA) in 5\% (w/v) skim milk in PBS/T. After washing six times for $10 \mathrm{~min}$ with $\mathrm{PBS} / \mathrm{T}$, the filters were incubated for $1 \mathrm{~min}$ with luminol enhanced chemiluminescence (ECL) substrate (Western Lightning, Perkin Elmer, Boston, MA, USA) and visualised by chemiluminescence for 10-60 sec using an X-ray Hyperfilm (Amersham Biosciences, Buckinghamshire, UK).

\section{Northern blot analysis}

Total RNA from cancer cell lines was isolated as described (Chang et al. 1997). Briefly, cells were sonicated in $\mathrm{LiCl} /$ urea solution on ice, centrifuged, phenol/chloroform extracted, ethanol precipitated and dissolved in sterile double distilled water. Total RNA $(20 \mu \mathrm{g})$ was loaded on a $1 \%$ denatured agarose gel, electrophoresed and blotted on Hybond-N+ membranes (Amersham Pharmacia Biotech, Buckinghamshire, UK). Hybridisation was performed using a labelled TRPS1 probe and a labelled human glyceraldehyde phosphate dehydrogenase (GAPDH) probe as loading control, as described previously (Chang et al. 1997).

For comparison of mRNA expression between normal and tumour tissues, a dot blot was purchased (Cancer Profiling Array II, BD Biosciences Clontech, Palo Alto, CA, USA). The blot contained paired cDNA samples amplified from total RNA of 19 different human tissues. Each pair consisted of normal and corresponding tumour tissue obtained from the same patient. In addition, cDNA samples of nine different human cancer cell lines were also spotted. A human ubiquitin probe was supplied and used as loading control. The TRPS1 and ubiquitin probes were labelled and hybridisation was performed according to the manufacturers instructions.

\section{Results}

\section{mRNA and protein expression of TRPS1 in human cancer cell lines}

Northern and Western blot analyses were performed to analyse TRPS1 mRNA and protein expression levels, respectively. Several human prostate and breast cancer cell lines were cultured in their appropriate media containing FCS (Fig. 1). mRNA was detected using a TRPS1 specific probe (Chang et al. 1997) and protein was detected using rabbit polyclonal anti-TRPS1 antibody SN653 (Chang et al. 2002). Panel A shows relative mRNA expression and panel $\mathrm{B}$ shows relative protein expression in prostate cancer cells and breast cancer cells. For prostate cancer cells, mRNA and protein expression is observed in LNCaP-FGC, LNCaP-LNO, PC3 and not in DU145. For breast cancer cells, relatively high mRNA and protein expression is observed in ZR-75-1, T-47D, MCF-7 and SK-BR-3. Relatively low mRNA and protein expression is observed in MDA-MB-231. These results demonstrate a positive correlation between TRPS1 mRNA and protein expression in both prostate and breast cancer cell lines.

\section{Effect of R1881 on mRNA and protein expression of TRPS1 in LNCaP-FGC cells}

The effect of the synthetic androgen R1881 on TRPS1 mRNA and protein expression levels was studied in androgen-dependent LNCaP-FGC cells (Fig. 2). Panel A shows mRNA expression and panel $\mathrm{B}$ shows protein expression. High expression is observed without R1881, and expression is lower in the presence of $0.1 \mathrm{nM}$ R 1881 and $10 \mathrm{nM}$ R1881. These results demonstrate that androgens down-regulate both mRNA and protein expression in LNCaP-FGC cells and furthermore that down-regulation occurs at the transcriptional level.

\section{Protein expression of TRPS1 in human prostate cancer xenografts}

Similary, androgenic regulation of TRPS1 was evaluated in human prostate cancer xenografts using rabbit polyclonal anti-TRPS1 antibody SN653 and the effect of 


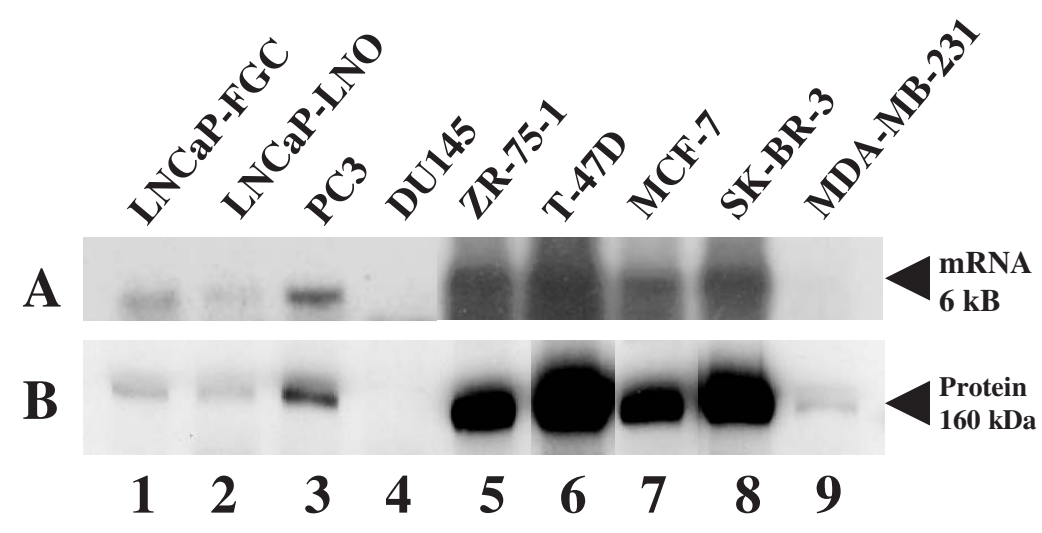

Figure 1 TRPS1 mRNA and protein expression in prostate and breast cancer cell lines (A) mRNA expression. Total RNA was isolated from cells and $20 \mu \mathrm{g}$ was loaded on a 1\% agarose gel. After electrophoresis, total RNA was blotted onto Hybond-N+ membranes and TRPS1 mRNA was visualised by autoradiography using a TRPS1-specific probe. A GAPDH probe was used as loading control (not shown). (B) Protein expression. Whole protein lysates were prepared and $20 \mu \mathrm{g}$ was loaded on a $7 \%$ SDS polyacrylamide slabgel. After electrophoresis, proteins were blotted onto nitrocellulose membranes and TRPS1 protein was visualised by chemiluminescence using rabbit polyclonal antibody SN653. Lanes 1-4, prostate cancer cell lines; lanes 5-9, breast cancer cell lines; lane 1, LNCaP-FGC; lane 2, LNCaP-LNO; lane 3, PC3; lane 4, DU145; lane 5, ZR-75-1; lane 6, T-47D; lane 7, MCF-7; lane 8: SK-BR-3 and lane 9: MDA-MB-231.

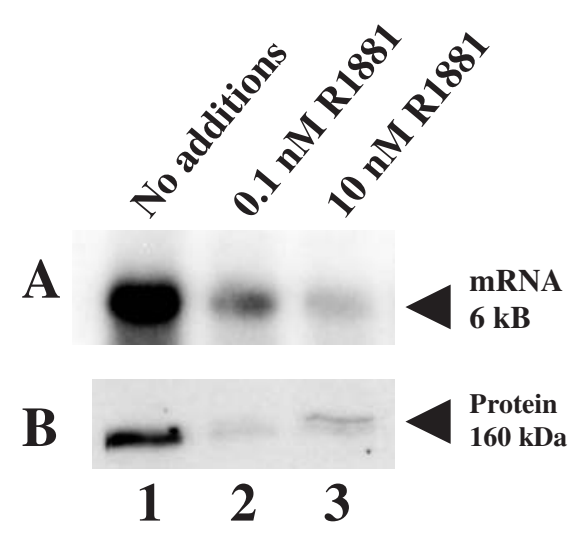

Figure 2 Effect of R1881 on TRPS1 mRNA and protein expression in LNCaP-FGC prostate cancer cell line. LNCaPFGC cells were grown to near confluency and preincubated in media without androgen (dextran charcoal treated FCS) for $24 \mathrm{~h}$. The synthetic androgen R1881 was added for an additional $24 \mathrm{~h}$ at final concentrations of $0,0.1$ and $10 \mathrm{nM}$. (A) mRNA expression. Total RNA was isolated from cells and $20 \mu \mathrm{g}$ was loaded on a $1 \%$ agarose gel. After electrophoresis, total RNA was blotted onto Hybond-N+ membranes and TRPS1 mRNA was visualised by autoradiography using a TRPS1 specific probe. A GAPDH probe was used as loading control (not shown). (B) Protein expression. Whole protein lysates were prepared and $20 \mu \mathrm{g}$ was loaded on a $7 \%$ SDS polyacrylamide slabgel. After electrophoresis, proteins were blotted onto nitrocellulose membranes and TRPS1 protein was visualised by chemiluminescence using rabbit polyclonal antibody SN653. Lane 1, no R1881; lane 2, $0.1 \mathrm{nM} \mathrm{R1881}$ and lane 3: $10 \mathrm{nM}$ R1881. castration was studied in a selected group of xenografts (Fig. 3). Panel A shows relative expression levels in a panel of six androgen-dependent xenografts (PC82, PC295, PC310, PC329, PC346 and PC346B) and eight androgen-independent xenografts (PC133, PC135, PC324, PC339, PC346I, PC346BI, PC374 and PC374F). In androgen-dependent xenografts, expression was observed in $\mathrm{PC} 82, \mathrm{PC} 310, \mathrm{PC} 346$ and $\mathrm{PC} 346 \mathrm{~B}$, and low expression in PC295 and PC329. In androgen-independent xenografts, expression was observed in PC135, PC339, PC346I and PC346BI, and was low or absent in PC133, PC324, PC374 and PC374F. Panel B shows relative expression levels of TRPS1 in xenografts after castration of the mice bearing PC295, PC310 and PC135 tumours. In androgendependent PC295 and PC310 xenografts expression is low before castration, and higher at 4 and 7 days postcastration. In androgen-independent PC135 xenograft expression is already high and not changed at 21 days postcastration. These results demonstrate that androgen withdrawal in vivo increases TRPS1 protein expression in the androgen-dependent xenografts PC295 and PC310, while TRPS1 expression remains high in the androgenindependent xenograft PC135.

\section{mRNA expression of TRPS1 in human normal and tumour tissues}

To evaluate mRNA expression levels of TRPS1 in a set of 19 human normal and tumour tissues, a dot blot containing cDNA samples amplified from total RNA was used. Paired tissues were obtained from the same patient. TRPS1 expression levels in four pairs of normal 


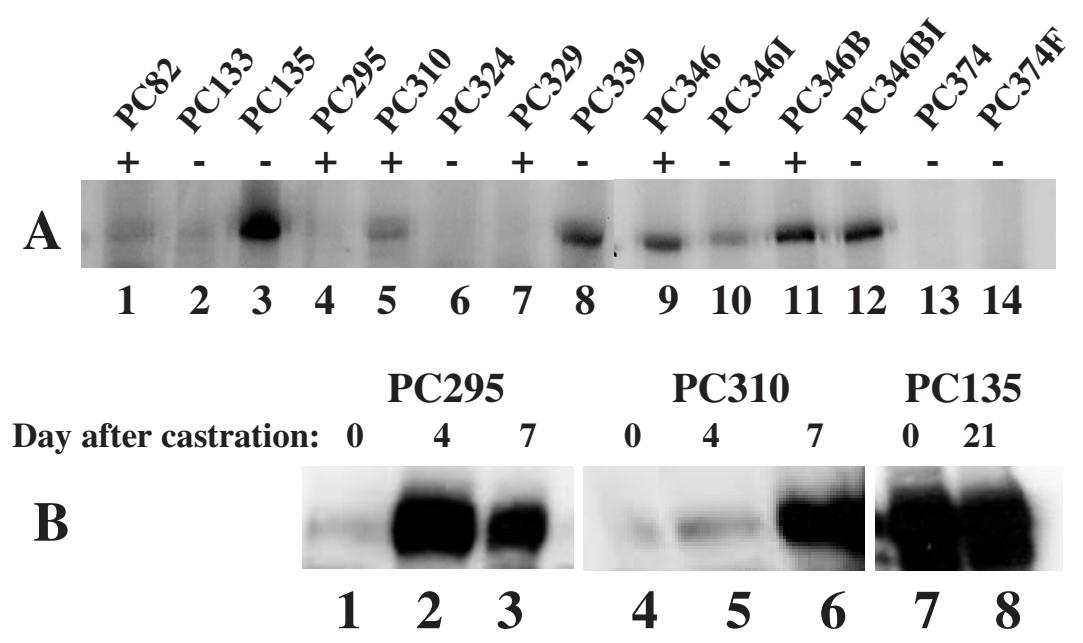

Figure 3 Effects of castration on TRPS1 protein expression in prostate cancer xenografts. Xenografts were propagated in male nude mice. For castration experiments, selected xenografts were propagated in male nude mice with testosterone implants. Castration was performed using hypnorm anaesthesia and removal of testosterone implants. Mice were sacrified and tumours were collected at indicated days. Whole tissue lysates were prepared and $20 \mu \mathrm{g}$ was loaded on a $7 \%$ SDS polyacrylamide slabgel. After electrophoresis, proteins were blotted onto nitrocellulose membranes and TRPS1 protein was visualised by chemiluminescence using rabbit polyclonal antibody SN653. (A) protein expression in androgen-dependent xenografts (PC82, PC295, PC310, PC329, $\mathrm{PC} 346$ and $\mathrm{PC} 346 \mathrm{~B})$ and androgen-independent xenografts (PC133, PC135, PC324, PC339, PC346I, PC346BI, PC374 and PC374F). Lane 1, PC82; lane 2, PC133; lane 3, PC135; lane 4, PC295; lane 5, PC 310; lane 6, PC324; lane 7, PC 329; lane 8, PC 339; lane 9, PC 346; lane 10, PC346I; lane 11, PC346B; lane 12, PC 346BI; lane 13, PC374 and lane 14, PC347F. +, androgendependent; —, androgen-independent. (B) Protein expression in androgen-dependent PC295 and PC310 and androgenindependent PC135 xenografts after castration. Lanes 1-3, PC295; lanes 4-6, PC310 and lanes 7 and 8, PC135. Lanes 1, 4 and 7, before castration; lanes 2 and 5, 4 days postcastration; lanes 3 and 6,7 days postcastration and lane 8, 21 days postcastration.

and tumour tissues of prostate is shown in Fig. 4A, lane 9. The highest TRPS1 expression levels were observed in all 10 pairs of normal and tumour tissues of breast (Fig. 4A, lane 1).

\section{Discussion}

In previous studies on TRPS1 expression, we have shown that TRPS1 mRNA is differentially expressed in the LNCaP prostate cancer cell model and may have a role in prostate cancer development (Chang et al. 1997). LNCaP cells were derived from a human prostatic adenocarcinoma metastatic to the lymph node (Horoszewicz et al. 1983). The cells express both AR and PSA and their growth is dependent on androgens. In later studies, cells were also called LNCaP-FGC. LNCaP-FGC cells maintained their malignant property by forming tumours in athymic mice after injection. From the LNCaP-FGC cells, a subline was developed that grows in the absence of androgens, these cells were called LNCaP-LNO. Growth characteristics in culture of this $\mathrm{LNCaP}$ model that consists of androgen-dependent LNCaP-FGC and androgen-independent LNCaP-LNO have been described (Chang et al. 1997). Next to these cells, we also studied two other prostate cancer cell lines, DU145 and PC3. DU145 cells were derived from a human prostatic adenocarcinoma metastatic to the brain (Stone et al. 1978). DU145 cells do not express AR and growth is independent of androgens. Furthermore, cells could form colonies when they were grown in a culture of soft agar suspension. PC3 cells were derived from a human prostatic adenocarcinoma metastatic to bone (Kaighn et al. 1979). Like DU145 cells, PC3 cells do not express AR and growth is not dependent on androgens. In nude mice, PC3 cells could produce subcutaneous tumours. Endogenous TRPS1 protein levels present in both prostate and breast cancer have not yet been reported. We have analysed TRPS1 mRNA and protein expression levels in a panel of four prostate and five breast cancer cell lines. For the prostate cancer cell lines, mRNA and protein expression was observed in three out of four cancer cell lines. For the breast cancer cell lines, high expression of mRNA and protein was observed in four out of five cancer cell lines. This shows a positive correlation between TRPS1 mRNA and protein expression in two different types of endocrine-related cancer cell lines. To investigate whether this correlation is influenced by androgens, we have analysed mRNA and protein expression in LNCaPFGC cells grown in the presence of increasing concentrations of the synthetic androgen R1881. We show that both mRNA and protein levels are down-regulated by R1881 to the same extent. This correlation indicates that TRPS1 


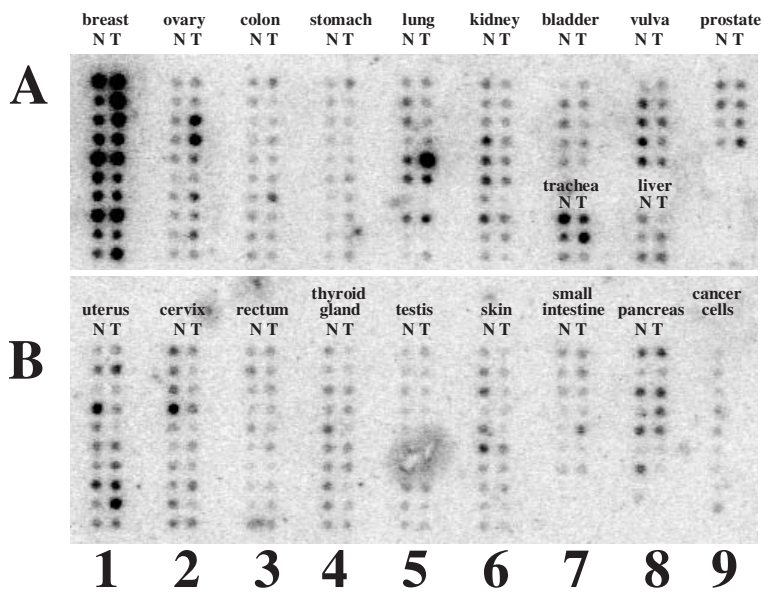

Figure 4 TRPS1 mRNA expression in normal and tumour tissues. Total RNA was isolated from human tissues, amplified to cDNA and spotted on a dot blot (BD Biosciences Clontech, Palo Alto, CA, USA). The blot contains paired cDNA samples derived from 19 different tissues. Each pair consists of normal $(\mathrm{N})$ and tumour $(\mathrm{T})$ tissue derived from the same patient. Tissue samples vary between 3 and 10 patients. Hybridisation was performed using a radiolabelled TRPS1 probe, according to the manufacturer's instructions. A ubiquitin probe was used as loading control (not shown). (A) Column 1, breast; column 2, ovary; column 3 , colon; column 4 , stomach; column 5 , lung; column 6, kidney; column 7, bladder (upper part) and trachea (lower part); column 8, vulva (upper part) and liver (lower part) and column 9, prostate. (B) Column 1, uterus; column 2, cervix; column 3, rectum; column 4, thyroid gland; column 5 , testis; column 6 , skin; column 7 , small intestine; column 8 , pancreas and column 9, human cancer cell lines. (From top to bottom: HeLa, Daudi, K562, HL60, G361, A549, MOLT4, SW480 and Raji cells, respectively).

protein down-regulation by $\mathrm{R} 1881$ is mediated at the transcriptional level.

Previously, we have shown that TRPS1 mRNA expression is increased in the ventral prostate of the rat after androgen removal by castration, suggesting androgenic regulation in rodents (Chang et al. 2000). Androgenic regulation of both TRPS1 mRNA and protein expression in human prostate cancer has not yet been reported. We have analysed TRPS1 protein expression using a panel of six androgen-dependent and eight androgen-independent human prostate cancer xenografts. The androgen-dependent xenografts (PC82, PC295, PC310, PC329, PC346 and PC346B) express AR and PSA and their growth depends on androgen (van Weerden et al. 1996, van Weerden \& Romijn 2000). The androgen-independent xenografts PC133, PC135, PC324 and PC339 do not express AR and PSA, whereas the androgen-independent xenografts PC346I, PC346BI, PC374, and PC374F do express AR and PSA. TRPS1 protein expression is observed in all six androgen- dependent xenografts. In the eight androgen-independent xenografts, expression is observed in four xenografts and expression is low or absent in four xenografts. These results demonstrate a heterogenous expression pattern in the panel of androgen-independent xenografts. Castration of mice carrying the androgen-dependent xenografts PC295 and PC310 demonstrates that TRPS1 expression is increased, likely mediated by the action of the AR since PSA levels are simultaneously reduced. However, the increase is different between the two xenografts. In PC295, TRPS1 is increased 4 days postcastration, whereas in PC310 the increase occurs at 7 days postcastration. In androgen-independent xenograft PC135, TRPS1 expression levels remain the same before and after castration. This is likely due to the absence of AR in PC135. When the AR is absent, TRPS1 can still be expressed and has escaped androgenic regulation via bypassing AR action. This alternative pathway is unknown and is currently under investigation.

The androgenic regulation of TRPS1 protein expression in xenografts showed comparable results as with TRPS1 mRNA expression in xenografts using microarray analysis (P J M Hendriksen \& G Jenster, unpublished observation). Preliminary results showed increasing TRPS1 mRNA expression after castration of mice carrying androgen-dependent xenografts PC82, PC295, PC310, and PC346 (AR positive). Castration of mice carrying androgen-independent xenografts PC133, PC135 and PC339 (AR negative) did not change TRPS1 mRNA expression levels.

We have shown that removal of androgens from the culture media of androgen-dependent LNCaP-FGC prostate cancer cells increases both TRPS1 mRNA and protein expression (Fig. 2). In the androgen-independent DU145 and PC3 prostate cancer cell lines, TRPS1 is not expressed in DU145 cells but is expressed in PC3 cells. Removal of androgen from the culture media of PC 3 cells does not increase TRPS1 mRNA and protein expression (not shown). This is due to the absence of AR in PC3 cells. This result is comparable with the results of the androgenindependent $\mathrm{PC} 135$ xenograft. This suggests that $\mathrm{LNCaP}-$ FGC and PC3 cells would be useful models to study TRPS1 regulation in androgen-dependent and androgenindependent prostate cancer cell lines.

Previously, we have shown that TRPS1 mRNA is ubiquitously expressed in human normal and foetal tissues (Chang et al. 2000). To investigate whether TRPS1 is expressed in human tumour tissues, we have analysed mRNA expression in normal and tumour material derived from the same patient. We observed that TRPS1 has the highest mRNA expression levels in normal and tumour breast tissues. Recently, it was reported that TRPS1 mRNA is highly expressed in four 
out of six breast cancer cell lines (Savinainen et al. 2004). Here, we confirm that there are high TRPS1 mRNA levels, but also high protein levels in four out of five breast cancer cell lines. In addition, expression data obtained from serial analysis of gene expression (SAGE) as published online (http://cgap.nci.nih.gov/SAGE) showed that TRPS1 had the highest expression levels in breast cancer libraries. For example, using the tag TTCTTGGTGT it was observed that TRPS1 was expressed in 70 libraries. Out of these libraries, the seven that expressed the highest TRPS1 levels were all derived from breast cancer tissues. Taken together, these data demonstrate relatively high TRPS1 expression levels in breast tumour tissues and breast cancer cell lines. This indicates that TRPS1 may play a role in breast cancer development and warrants further study.

\section{Acknowledgements}

We would like to thank the personnel of the EDC for animal husbandry and management. This work was supported by grant EUR2000-2264 of the Dutch Cancer Society, KWF Kankerbestrijding.

\section{References}

Arnold JT \& Isaacs JT 2002 Mechanisms involved in the progression of androgen-independent prostate cancers: it is not only the cancer cell's fault. Endocrine-Related Cancer $\mathbf{9}$ 61-73.

Chang GTG, Blok LJ, Steenbeek M, Veldscholte J, van Weerden WM, van Steenbrugge GJ \& Brinkmann AO 1997 Differentially expressed genes in androgen-dependent and independent prostate carcinomas. Cancer Research $\mathbf{5 7}$ 4075-4081.

Chang GTG, Steenbeek M, Schippers E, Blok LJ, van Weerden WM, van Alewijk DC, Eussen BH, van Steenbrugge GJ \& Brinkmann AO 2000 Characterization of a zinc-finger protein and its association with apoptosis in prostate cancer cells. Journal of the National Cancer Institute 92 1414-1421.

Chang GTG, van den Bemd GJ, Jhamai M \& Brinkmann AO 2002. Structure and function of GC79/TRPS1, a novel androgen-repressible apoptosis gene. Apoptosis 7 13-21.

Cher ML, Bova GS, Moore DH, Small EJ, Carroll PR, Pin SS, Epstein JI, Isaacs WB \& Jensen RH 1996 Genetic alterations in untreated metastases and androgen-independent prostate cancer detected by comparative genomic hybridization and allelotyping. Cancer Research 56 3091-3102.

Culig Z, Klocker H, Bartsch G \& Hobisch A 2002 Androgen receptors in prostate cancer. Endocrine-Related Cancer 9 $155-170$.

Feldman BJ \& Feldman D 2001 The development of androgenindependent prostate cancer. Nature Reviews Cancer 1 34-45.

Gelmann EP 2002 Molecular biology of the androgen receptor. Journal of Clinical Oncology 20 3001-3015.
Horoszewicz JS, Leong SS, Kawinski E, Karr JP, Rosenthal H, Chu TM, Mirand EA \& Murphy GP 1983 LNCaP model of human prostatic carcinoma. Cancer Research 43 1809-1818.

Huggins C \& Hodges CV 1941 Studies on prostatic cancer: I. The effect of castration, of estrogen and of androgen injection on serum phosphatases in metastatic carcinoma of the prostate. Cancer Research 1 293-297.

Jemal A, Tiwari RC, Murray T, Ghafoor A, Samuels A, Ward E, Feuer EJ \& Thun MJ 2004 Cancer statistics. CA: A Cancer Journal for Clinicians 54 8-29.

Kaighn ME, Narayan KS, Ohnuki Y, Lechner JF \& Jones LW 1979 Establishment and characterization of a human prostatic carcinoma cell line (PC-3). Investigative Urology 17 16-23.

Kaiser FJ, Tavassoli K, Van den Bemd GJ, Chang GTG, Horsthemke B, Möröy T \& Lüdecke HJ $2003 a$ Nuclear interaction of the dynein light chain LC8a with the TRPS1 transcription factor suppresses the transcriptional repression activity of TRPS1. Human Molecular Genetics 12 1349-1358.

Kaiser FJ, Möröy T, Chang GTG, Horsthemke B \& Lüdecke HJ $2003 b$ The RING finger protein RNF4, a co-regulator of transcription, interacts with the TRPS1 transcription factor. Journal of Biological Chemistry 278 38780-38785.

Kallioniemi A, Kallioniemi OP, Piper J, Tanner M, Stokke T, Chen L, Smith HS, Pinkel D, Gray JW \& Waldman FM 1994 Detection and mapping of amplified DNA sequences in breast cancer by comparative genomic hybridization. PNAS 91 2156-2160.

Lüdecke HJ, Schaper J, Meinecke P, Momeni P, Gross S, von Holtum D, Hirche H, Abramowicz MJ, Albrecht B, Apacik C, Christen HJ, Claussen U, Devriendt K, Fastnacht E, Forderer A, Friedrich U, Goodship TH, Greiwe M, Hamm H, Hennekam RC, Hinkel GK, Hoeltzenbein M, Kayserili H, Majewski F, Mathieu M, McLeod R, Midro AT, Moog U, Nagai T, Niikawa N, Orstavik KH, Plochl E, Seitz C, Schmidtke J, Tranebjaerg L, Tsukahara M, Wittwer B, Zabel B, Gillessen-Kaesbach G \& Horsthemke B 2001 Genotypic and phenotypic spectrum in tricho-rhino-phalangeal syndrome types I and III. American Journal of Human Genetics 68 81-91.

Malik TH, Shoichet SA, Latham P, Kroll TG, Peters LL \& Shivdasani RA 2001 Transcriptional repression and developmental functions of the atypical vertebrate GATA protein TRPS1. European Molecular Biology Organization Journal 20 1715-1725.

Martel CL, Gumerlock PH, Meyers FJ \& Lara PN 2003 Current strategies in the management of hormone refractory prostate cancer. Cancer Treatment Reviews 29 171-187.

Moilanen AM, Poukka H, Karvonen U, Hakli M, Janne OA \& Palvimo JJ 1998 Identification of a novel RING finger protein as a coregulator in steroid receptor-mediated gene transcription. Molecular and Cellular Biology 18 5128-5139.

Momeni P, Glockner G, Schmidt O, von Holtum D, Albrecht B, Gillessen-Kaesbach G, Hennekam R, Meinecke P, Zabel B, Rosenthal A, Horsthemke B \& Lüdecke HJ 2000 Mutations in a new gene, encoding a zinc-finger protein, cause tricho-rhino-phalangeal syndrome type I. Nature Genetics $\mathbf{2 4}$ 71-74. 
Nupponen NN, Kakkola L, Koivisto P \& Visakorpi T 1998 Genetic alterations in hormone-refractory recurrent prostate carcinomas. American Journal of Pathology 153 141-148.

Savinainen KJ, Linja MJ, Saramki OR, Tammela TLJ, Chang GTG, Brinkmann AO \& Visakorpi T 2004 Expression and copy number analysis of TRPS1, EIF3S3 and MYC genes in breast and prostate cancer. British Journal of Cancer $\mathbf{9 0}$ 1041-1046.

Stone KR, Mickey DD, Wunderli H, Mickey GH \& Paulson DF 1978 Isolation of a human prostate carcinoma cell line (DU 145). International Journal of Cancer 21 274-281.

Tirkkonen M, Tanner M, Karhu R, Kallioniemi A, Isola J \& Kallioniemi OP 1998 Molecular cytogenetics of primary breast cancer by CGH. Genes Chromosomes and Cancer 21 177-184.

van den Bemd GJ, Jhamai M, Brinkmann AO \& Chang GTG 2003 The atypical GATA protein TRPS1 represses androgeninduced prostate-specific antigen expression in LNCaP prostate cancer cells. Biochemical and Biophysical Research Communications 312 578-584. van Weerden WM \& Romijn JC 2000 Use of nude mouse xenograft models in prostate cancer research. Prostate $\mathbf{4 3}$ 263-271.

van Weerden WM, de Ridder CM, Verdaasdonk CL, Romijn JC, van der Kwast TH, Schröder FH \& van Steenbrugge GJ 1996 Development of seven new human prostate tumor xenograft models and their histopathological characterization. American Journal of Pathology 149 1055-1062.

Visakorpi T, Kallioniemi AH, Syvanen AC, Hyytinen ER, Karhu R, Tammela T, Isola JJ \& Kallioniemi OP 1995 Genetic changes in primary and recurrent prostate cancer by comparative genomic hybridization. Cancer Research $\mathbf{5 5}$ 342-347.

Weir HK, Thun MJ, Hankey BF, Ries LA, Howe HL, Wingo PA, Jemal A, Ward E, Anderson RN \& Edwards BK 2003 Annual report to the nation on the status of cancer, 1975 2000 , featuring the uses of surveillance data for cancer prevention and control. Journal of the National Cancer Institute 95 1276-1299. 